\title{
Soil chemical properties affected by cover crops under no-tillage system
}

\author{
Adriano Stephan Nascente ${ }^{1 *}$, Luis Fernando Stone ${ }^{2}$, Carlos Alexandre Costa Crusciol ${ }^{3}$
}

http://dx.doi.org/10.1590/0034-737X201562040010

\begin{abstract}
The use of cover crops in no-tillage systems (NTS) can significantly improve the soil's fertility. Thus, a study was performed to evaluate changes in chemical properties of soil caused by cover crops in a no-tillage system. The field experiment consisted of the following crop rotation: cover crops/rice/cover crops/rice. The experimental design was in randomized blocks with three replications. Treatments consisted of four cover crops (Brachiaria brizantha (Hochst. ex A. Rich.) Stapf. cv. Marandu, Brachiaria ruziziensis R. Germ. and C.M. Evrard, Panicum maximum Jacq. cv. Colonião, and Pennisetum glaucum (L.) R. Br. cv. BN-2) and fallow (control treatment). Soil samples were collected at the beginning of the summer crop in Oct 2007, Oct 2008 and Oct 2009 at 0-5 cm soil depth. The use of cover crops provided for a significant increase in the level of nutrients, soil organic matter, cation exchange capacity, and base saturation in the soil. Soil fertility improved from the first to second year with the growing of cover crops. The soil under cover crops P. glaucum, B. ruziziensis, and B. brizantha showed higher fertility than the area under fallow.

Key words: Brachiaria brizantha (Hochst. ex A. Rich.) Stapf. cv. Marandu, Brachiaria ruziziensis R. Germ. and C.M. Evrard, Panicum maximum Jacq. cv. Colonião, Pennisetum glaucum (L.) R. Br. cv. BN-2, soil management.
\end{abstract}

\section{RESUMO}

\section{Propriedades químicas do solo afetadas por plantas de cobertura no sistema plantio direto}

$\mathrm{O}$ uso de plantas de cobertura no sistema de plantio direto (SPD) pode melhorar significativamente a fertilidade do solo. Assim, um estudo foi realizado para avaliar as alterações nas propriedades químicas do solo causadas pelas culturas de cobertura em sistema de plantio direto. $\mathrm{O}$ experimento de campo consistiu na rotação das seguintes culturas: plantas de cobertura/ arroz/ plantas de cobertura/ arroz. O delineamento experimental foi em blocos casualizados com três repetições. Os tratamentos consistiram de quatro espécies de plantas de cobertura (Brachiaria brizantha (Hochst. ex A. Rich.) Stapf. cv. Marandu, Brachiaria ruziziensis R. Germ. and C.M. Evrard, Panicum maximum Jacq. cv. Colonião and Pennisetum glaucum (L.) R. Br. cv. BN-2) e pousio (tratamento controle). As amostras foram coletadas no início da safra de verão, em outubro de 2007, 2008 e 2009, a 0-5 cm de profundidade. $\mathrm{O}$ uso de plantas de cobertura proporcionou aumento significativo na concentração de nutrientes, matéria orgânica do solo, capacidade de troca catiônica e saturação por bases. A fertilidade do solo melhorou do primeiro para o segundo ano com o cultivo de plantas de cobertura. O solo sob as plantas de cobertura P. glaucum, B. ruziziensis e B. brizantha apresentou maior fertilidade do que a área mantida sob pousio.

Palavras-chave: Brachiaria brizantha (Hochst. ex A. Rich.) Stapf. cv. Marandu, Brachiaria ruziziensis R. Germ. and C.M. Evrard, Panicum maximum Jacq. cv. Colonião, Pennisetum glaucum (L.) R. Br. cv. BN-2, manejo do solo.

\footnotetext{
Submitted on 10/25/2012 and approved on 07/06/2015.

${ }^{1}$ Embrapa Arroz e Feijão, Santo Antônio de Goiás, Goiás, Brazil. adriano.nascente@embrapa.br

${ }^{2}$ Embrapa Arroz e Feijão, Santo Antônio de Goiás, Goiás, Brazil. luis.stone @embrapa.br

${ }^{3}$ Universidade Estadual Paulista, Faculdade de Ciências Agronômicas, Departamento de Produção Vegetal, Botucatu, São Paulo, Brazil. crusciol@ fca.unesp.br

*Autor para correspondência: adriano.nascente@embrapa.br
} 


\section{INTRODUCTION}

The use of no-tillage systems (NTS) is growing in all regions of Brazil, occupying an area of 25 million hectares, about 10 million of which are located in soils under Cerrado (CONAB, 2012). These soils are characterized by low soil fertility and low pH (Boer et al., 2007). Using cover crops in NTS could be an important alternative to increase the sustainability of agricultural systems, which may favor increasing soil fertility, and restoring considerable amounts of nutrients to crops. Cover crops with large root systems can uptake nutrients from deep soil layers and after chemical desiccation, during straw degradation, release these nutrients in the soil surface (Duda et al., 2003; Boer et al., 2007; Torres \& Pereira, 2008; Pacheco et al., 2011; Cunha et al., 2011). Therefore, vegetation at the soil surface in the NTS can significantly change the chemical properties of the soil (Torres et al., 2005; Crusciol et al., 2005; Rosolem et al., 2006; Boer et al., 2007; Carpim et al., 2008, Garcia et al., 2008; Reddy et al., 2009, Carneiro et al., 2009; Rosolem et al., 2010; Cunha et al., 2011).

In this sense, it is essential to be aware of the changes caused by cover crops, for understanding the process, which could result in more efficient use of nutrients for subsequent crops (Fabian, 2009). Sá (1993) reported that soils under NTS for 4, 9, and 16 years had values of 29, 79, and $129 \mathrm{mg} \mathrm{kg}^{-1}$ of $\mathrm{P}$, respectively, in the 0-2.5 cm layer. Sá (1993), Crusciol et al. (2008), and Crusciol et al. (2010) reported an increase in the contents of $\mathrm{K}^{+}$in the $0-5 \mathrm{~cm}$ soil layer by using cover crops in NTS. Other studies have also described accumulation in the soil surface of $\mathrm{Ca}^{2+}$ and $\mathrm{Mg}^{2+}$ (Falleiros et al., 2003), and $\mathrm{Zn}^{2+}, \mathrm{Mn}^{2+}, \mathrm{Fe}^{2+}$, and $\mathrm{Cu}^{2+}$ (Franzluebbers \& Hons, 1996), increases in cation exchange capacity, organic matter content, $\mathrm{P}$ and $\mathrm{K}^{+}$ (Santos \& Tomm, 2003; Bernardi et al., 2005; Crusciol et al., 2010), as well as changes in $\mathrm{pH}$ and reduced $\mathrm{Al}$ saturation (Cunha et al., 2011).

Additionally, according to Santi et al. (2003), Bernardi et al. (2005), and Fabian (2009), after a while, in NTS there is a tendency to increase the efficiency of the applied fertilizers and the availability of nutrients by the action of microorganisms $(\mathrm{N})$, decrease fixation of nutrients $(\mathrm{P})$ and movement of cations in the soil profile $\left(\mathrm{Ca}^{2+}, \mathrm{Mg}^{2+}\right.$, and $\left.\mathrm{K}^{+}\right)$. In this sense, it is important to develop studies to assess the contributions of cover crops in soil fertility, aiming to increase crop yield, reducing production costs and increasing the overall sustainability of the system (Bernarndi et al., 2005; Torres \& Pereira, 2008; Crusciol et al., 2010). Thus, a study was performed to evaluate changes in the soil's chemical properties caused by cover crops in NTS.

\section{MATERIALAND METHODS}

\section{Site descriptions}

The field experiment was conducted in Santo Antônio de Goiás, in the Brazilian state of Goais $\left(16^{\circ} 27^{\prime}\right.$ latitude, $49^{\circ} 17^{\prime}$ longitude, and $823 \mathrm{~m}$ local elevation). The regional climate is tropical savanna, classified as Aw according to the Köppen classification. There are two well defined seasons, normally dry from May to September (autumn/winter) and wet from October to April (spring/summer), annual mean rainfall is between $1500 \mathrm{~mm}$ and $1700 \mathrm{~mm}$. Local annual mean temperature is $22.7^{\circ} \mathrm{C}$, varying annually from $14.2^{\circ} \mathrm{C}$ to $34.8^{\circ} \mathrm{C}$.

The soil was a Brazilian Oxisol (Embrapa, 1999) found in a gently undulating topography. Soil texture was clayey (540 $\mathrm{g} \mathrm{kg}^{-1}$ clay, $110 \mathrm{~g} \mathrm{~kg}^{-1}$ silt, and $350 \mathrm{~g} \mathrm{~kg}^{-1}$ sand). The research was conducted in an area that had been under NTS for six years (2001/2002 - 2006/2007) in rotations with corn $(2001 / 2002,2003 / 2004$, and 2005/2006) and soybean (2002/2003, 2004/2005, and $2006 / 2007$ ) in the summer and fallow in the winter.

\section{Experimental design and treatments}

The experiment consisted of cover crops in the first summer (November - 2007) and rice in the second summer (November - 2008). After the rice harvesting, it was sowed with the same cover crops in the off-season (March - 2009) and followed by rice again in the third summer (November - 2009). Cover crops used were: 1. Panicum maximum, 2. - Brachiaria ruziziensis, 3. Brachiaria brizantha - cultivar Marandu and 4. - millet (Pennisetum glaucum - cultivar BN-2) and 5. Fallow (spontaneous vegetation, predominantly Bidens pilosa L., Commelina benghalensis L., Conyza bonariensis L. Cronquist, and Cenchrus echinatus L.). The experimental design was randomized blocks in a split plot scheme. In the main plots there were five cover crops and in the subplots there were two years (2008 and 2009) of evaluation, with three replications.

\section{Crop management}

Tropical forages are sown in November 2007 and March 2009, and millet was sown in March 2008 and March 2009. It used $0.20 \mathrm{~m}$ row spacing with a mechanical planter set to distribute $10 \mathrm{~kg}$ of seeds per $\mathrm{ha}^{-1}$ as recommended by Crusciol et al. (2010).

Rice was sown in November of 2008 (second summer) and November of 2009 (third summer) using the cultivar "BRS Sertaneja" spaced at $0.35 \mathrm{~m}$ with 80 seeds per meter. The sowing fertilization was $400 \mathrm{~kg}$ $\mathrm{ha}^{-1}$ of the 04-30-16 NPK formula. Immediately after sowing, fertilization of $45 \mathrm{~kg} \mathrm{ha}^{-1}$ of $\mathrm{N}$ as urea was made. Cultural practices were performed in 
accordance with the recommendations of the culture (EMBRAPA Arroz e Feijão, 2003).

\section{Soil sampling}

Three replications (composite sample) of 16 single samples each in the layer $0-5 \mathrm{~cm}$ depth for chemical analysis of the soil were collected before installation of the experiment to evaluate the initial fertility, one month after the application of limestone $\left(1 \mathrm{t} \mathrm{ha}^{-1}\right)$. To evaluate changes caused by cover crops in the soil's chemical properties, samples were collected in October 2008 and October 2009. Eight single soil samples were collected from each plot in the layers of $0-5 \mathrm{~cm}$. Single samples were manually mixed and homogenized to form a composite sample of each plot. These samples were packed separately in plastic bags and sent for chemical analysis, according to the methodology of Embrapa's manual of methods (Claessen, 1997).

\section{Soil analysis}

The $\mathrm{pH}$ was determined in water, using a soil:solution ratio of 1:2.5. $\mathrm{P}$ and $\mathrm{K}^{+}$were extracted by Mehlich 1 , and $\mathrm{Ca}^{2+}, \mathrm{Mg}^{2+}$ and $\mathrm{Al}^{3+}$ with $1 \mathrm{~mol} \mathrm{~L}{ }^{-1} \mathrm{KCl}$. In the extracted solution, $\mathrm{P}$ was determined by colorimetry and $\mathrm{K}^{+}$by flame photometry. $\mathrm{Ca}^{2+}$ and $\mathrm{Mg}^{2+}$ were determined by EDTA titration and $\mathrm{Al}^{3+}$ by titration of $\mathrm{NaOH}$ from the extract. Micronutrients were determined on a portion of the extract for P by atomic absorption spectrophotometry. Soil organic matter was determined by Walkley \& Black's method and the cation exchange capacity at $\mathrm{pH} 7.0$ and base saturation were also calculated.

\section{Statistical analysis}

The analysis of variance (ANOVA) and LSD tests at $\mathrm{p}<0.05$ were carried out using the SAS system statistical package (SAS, 1999). First, we performed an ANOVA and means test between the five cover crops (main plot) and the years 2008 and 2009 (subplots) at $\mathrm{p}<0.05$. Then, we performed another ANOVA to compare each year (2008 and 2009) with the initial fertility (2007), using Dunnett's test at $\mathrm{p}<0.05$.

\section{RESULTS AND DISCUSSION}

It was possible to observe that cover crops significantly affected contents of nutrients in the soil (Tables 1 and 2). There was interaction between cover crops and years for $\mathrm{pH}$. In the year 2008, soil under the cover crops $P$. maximum (6.8), B. ruziziensis (6.8) and P. glaucum (6.7) provided the highest values and differed from soil under fallow (6.3). However, in 2009, the $\mathrm{pH}$ of the soil under fallow was higher than that of the soil under $P$. maximum and did not differ from those under other cover crops. Guimarães (2000) and Moreti et al.
(2007) reported that cover crops could significantly affect the soil $\mathrm{pH}$. Plants have exudation of acids to the soil from their roots that could act directly on the soil $\mathrm{pH}$ (Moreti et al., 2007). Almost all cover crops provided for a reduction of the soil pH, from 2008 to 2009, the only exception was $B$. brizantha, which did not allow for differences between the years. According to Sá (1993), Franchini et al. (2000) and Fabian (2009) not tilling the soil favors nutrient accumulation at the surface, increased contents of soil organic matter and reduction in $\mathrm{pH}$ values. In addition, when soil organic matter is mineralized there is production of organic acids that could contribute to increased soil acidity (Garcia \& Rosolem, 2010).

The $\mathrm{pH}$ values were different and lower than the initial fertility at 2007 in the second year of evaluation under all cover crops (2009) (Table 3). This may be due to the removal of bases by the plants grown in this area. According to Oliveira \& Pavan (1996), Mello et al. (2003), Caires et al. (2006), and Soratto \& Crusciol (2007), in a no-tillage system the effect of limestone lasts longer than under conventional tillage, however, after the limestone application and with growing plants there is continued base $\left(\mathrm{K}^{+}, \mathrm{Mg}^{+2}\right.$, and $\left.\mathrm{Ca}^{+2}\right)$ removal that normally provides for a reduction in the soi $\mathrm{pH}$. Because of this, it is normally necessary to apply limestone again after seven years.

Cover crops and year did not affect $\mathrm{P}$ contents in the soil (Table 1). In the year 2008, soil under fallow (10.8 $\mathrm{mg} \mathrm{dm}^{-3}$ of P) and P. glaucum (11.2 $\mathrm{mg} \mathrm{dm}^{-3}$ of P) differed from the initial fertility (2007) (13.8 $\mathrm{mg} \mathrm{dm}^{-3}$ of P) (Table 3 ). This seems that fallow and millet did not cycle enough $\mathrm{P}$ and provided for a decrease in the level of this nutrient in the soil. In the year 2009, cover crops did not provide any differences in the soil's P contents in relation to the initial fertility (2007).

There was interaction between cover crops and years for calcium concentrations in the soil (Table 1). In the year 2008, soil under millet, fallow and B. ruziziensis provided the highest values and differed from the treatment with B. brizantha. In the year 2009, soil under $P$. maximum provided the lowest values of $\mathrm{Ca}$ and differed from fallow, B. ruziziensis and B. brizantha. According to Pacheco et al. (2014) cover crops can significantly change the soil attributes and depends on many factors, especially the species. Values of $\mathrm{Ca}$ in the soil with cover crops, increased from 2008 to 2009, however soil under fallow and millet did not differ significantly between the years. These increased in the values of Ca could be because during the process of cover crop degradation the release of this nutrient could occur, since we did not apply liming or fertilizer with calcium after installation of the experiment. 
In the year 2008, calcium values in the soil with cover crops were similar to the initial fertility seen in 2007 (Table 3). However, in 2009 soil under the cover crops $B$. ruziziensis and $B$. brizantha provided the highest values and differed from the initial fertility. According to Kluthcouski et al. (2000), Brachiaria species, due to their large and depth root systems, have greater ability to mobilize nutrients from deep soil layers to the topsoil. In this regard, soil under the cover crops evaluated provided higher cycling of magnesium and in the year 2009 soils under all cover crops were different from the initial fertility seen in 2007 (Table 3). Additionally, it was observed that there was an increase in the mean of soil magnesium contents from 2008 to 2009, provided by the use of all the cover crops evaluated (Table 1). From these results, it could be inferred that there is a great importance of using cover crops to cycle these nutrients.

Regarding potassium concentration in the soil, there was only the effect of cover crops (Table 1). On average, soil under fallow allowed the lowest $\mathrm{K}^{+}$concentration and it differed from soil under all cover crops, with the exception of $P$. glaucum and B. ruziziensis. According to Crusciol et al. (2010), forage grasses have great potential for the absorption and accumulation of $\mathrm{K}^{+}$, which is returned to the ground after their desiccation. Garcia et al. (2008) added that these forages provide non exchangeable $\mathrm{K}^{+}$to the soil, and this can lead to a reduction in spending for fertilizers in crop cultivation and, consequently, reduces the cost of production.

It was also observed that soil under $P$. maximum and B. brizantha in the first year (2008) and soil under all

Table 1: Soil's chemical attributes ( $\mathrm{pH}, \mathrm{P}, \mathrm{Ca}^{2+}, \mathrm{Mg}^{2+}, \mathrm{K}^{+}$, and $\mathrm{SOM}$ ) in the 0-5 $\mathrm{cm}$ depth, as a function of the cover crops (plot) and year (subplot), Santo Antônio de Goiás, 2008/2009 and 2009/2010

\begin{tabular}{|c|c|c|c|c|c|c|}
\hline \multirow[t]{2}{*}{ Cover crop } & 2008 & 2009 & Average & 2008 & 2009 & Average \\
\hline & \multicolumn{3}{|c|}{ pH (water) } & \multicolumn{3}{|c|}{$P\left(\mathrm{mg} \mathrm{dm}^{-3}\right)$} \\
\hline Fallow & $6.3 \mathrm{cA} \S$ & $5.8 \mathrm{abB}$ & 6.0 & 10.8 & 13.3 & 12.0 \\
\hline P. maximum & $6.8 \mathrm{aA}$ & $5.6 \mathrm{cB}$ & 6.2 & 11.8 & 12.8 & 12.3 \\
\hline B. ruziziensis & $6.8 \mathrm{aA}$ & $5.8 \mathrm{abB}$ & 6.3 & 13.8 & 15.6 & 14.7 \\
\hline B. brizantha & $6.4 \mathrm{bcA}$ & $5.7 \mathrm{bcA}$ & 6.1 & 11.8 & 15.9 & 13.9 \\
\hline P. glaucum & $6.7 \mathrm{abA}$ & $5.9 \mathrm{aB}$ & 6.3 & 11.2 & 16.7 & 13.9 \\
\hline \multirow[t]{2}{*}{ Average } & 6.6 & 5.7 & - & 12.1 & 14.7 & - \\
\hline & \multicolumn{3}{|c|}{$\mathrm{Ca}^{2+}\left(\mathrm{mol} \mathrm{dm}^{-3}\right)$} & \multicolumn{3}{|c|}{$\mathrm{Mg}^{2+}\left(\mathrm{mol} \mathrm{dm} \mathbf{d m}^{-3}\right)$} \\
\hline Fallow & $2.57 \mathrm{aA}$ & $2.83 \mathrm{aA}$ & 2.70 & 0.87 & 1.27 & 1.10 \\
\hline P. maximum & $2.33 \mathrm{abB}$ & $2.57 \mathrm{bA}$ & 2.45 & 0.97 & 1.40 & 1.20 \\
\hline B. ruziziensis & $2.57 \mathrm{aB}$ & $2.90 \mathrm{aA}$ & 2.75 & 0.93 & 1.40 & 1.20 \\
\hline B. brizantha & $2.17 \mathrm{bB}$ & $3.00 \mathrm{aA}$ & 2.60 & 0.90 & 1.57 & 1.25 \\
\hline P. glaucum & $2.70 \mathrm{aA}$ & $2.90 \mathrm{abA}$ & 2.80 & 1.13 & 1.27 & 1.20 \\
\hline \multirow[t]{2}{*}{ Average } & 2.51 & 2.80 & - & $0.96 \mathrm{~B}$ & $1.38 \mathrm{~A}$ & - \\
\hline & \multicolumn{3}{|c|}{$\mathrm{K}^{+}\left(\mathbf{m o l ~ d m ^ { - 3 }}\right)$} & \multicolumn{3}{|c|}{ SOM $\left(\mathrm{g} \mathrm{dm}^{-3}\right)$} \\
\hline Fallow & 0.38 & 0.34 & $0.36 \mathrm{~b}$ & $18.4 \mathrm{cB}$ & $22.9 \mathrm{bA}$ & 20.7 \\
\hline P. maximum & 0.61 & 0.64 & $0.62 \mathrm{a}$ & $20.6 \mathrm{bB}$ & $23.0 \mathrm{bA}$ & 21.8 \\
\hline B. ruziziensis & 0.51 & 0.54 & $0.53 \mathrm{ab}$ & $21.4 \mathrm{bA}$ & $22.9 \mathrm{bA}$ & 22.2 \\
\hline B. brizantha & 0.60 & 0.62 & $0.61 \mathrm{a}$ & $21.8 \mathrm{aA}$ & $23.9 \mathrm{bA}$ & 22.8 \\
\hline P. glaucum & 0.43 & 0.49 & $0.46 \mathrm{ab}$ & $21.6 \mathrm{aB}$ & $24.2 \mathrm{aA}$ & 22.9 \\
\hline Average & 0.50 & 0.53 & - & 20.8 & 23.4 & - \\
\hline \multirow{2}{*}{ Factor } & \multicolumn{6}{|c|}{ ANOVA (Mean Square) } \\
\hline & pH & $\mathbf{P}$ & $\mathrm{Ca}^{+2}$ & $\mathrm{Mg}^{+2}$ & $\mathbf{K}^{+}$ & SOM \\
\hline Block & 0.012 & 14.281 & 0.008 & 0.002 & 0.011 & 0.085 \\
\hline Cover crop (CC) & $0.089^{* *}$ & 7.848 & 0.115 & 0.024 & $0.076^{*}$ & $4.938^{* *}$ \\
\hline Error (a) & 0.011 & 2.422 & 0.039 & 0.029 & 0.001 & 0.214 \\
\hline Year & $5.720^{* *}$ & 49.923 & $0.645^{* *}$ & $1.323^{* *}$ & 0.005 & $25.208^{* *}$ \\
\hline CC $*$ Year & $0.127^{* *}$ & 8.227 & $0.168^{*}$ & 0.055 & 0.006 & $4.510^{* *}$ \\
\hline Error (b) & 0.019 & 3.494 & 0.033 & 0.009 & 0.001 & 0.222 \\
\hline CV Plot (\%) & 1.71 & 11.64 & 7.47 & 14.37 & 6.89 & 2.10 \\
\hline CV Subplot (\%) & 2.26 & 13.98 & 6.85 & 19.99 & 6.16 & 2.14 \\
\hline
\end{tabular}

$\S$ Means followed by the same letter, lowercase vertically or upper cases horizontally, do not differ by the LSD at $\mathrm{p} \leq 0.05$. $\mathrm{pH}$ : hydrogen potential, $\mathrm{P}$ : phosphorus; $\mathrm{Ca}^{2+}$ : calcium, $\mathrm{Mg}^{2+}$ : magnesium, $\mathrm{K}^{+}$: potassium, $\mathrm{SOM}$ : soil organic matter. ${ }^{* * *}$ Significant at $\mathrm{p}<0.05$ and 0.01 , respectively. 
cover crops, with the exception of fallow, in the second year (2009), differed from the initial fertility in 2007 (Table 3). With this result, we could infer that cover crops in a no-tillage system allowed for increases in $\mathrm{K}^{+}$ contents in the soil.

In relation to soil organic matter (SOM), there was interaction between cover crops and years (Table 1). It was possible to see that, in 2008, soil under fallow provided the lowest values of SOM and differed from the soil with all cover crops. The use of fallow in crop areas was not interesting because it can increase the weed infestation and, as our results showed, fallow could increase the SOM, but cover crops increased more. Therefore, the use of cover crops seems to be much more interesting than the use of fallow. In the second year (2009), soil under millet provided the highest value and differed from the others treatments. According to Nascente et al. (2013), millet is a cover crop that could increase soil organic matter and release nitrogen to the soil for the plants. Soil organic matter contents increased in value from 2008 to 2009, the only exceptions were treatments with $B$. ruziziensis and B. brizantha, these values did not significantly differ. The use of cover crops in no-tillage systems, due to keeping straw on the soil surface without plowing, normally provides for increases in the soil's organic matter through the years (Crusciol et al., 2010; Nascente et al., 2013).

Soil under all cover crops were different from initial fertility at 2007 in the second year (2009), showing the importance to use cover crops to increase SOM content (Table 3). Also Cunha et al. (2011) found an increase in SOM in soils under NTS cultivated with forage.

Table 2: Soil's chemical attributes (CEC, BS, $\mathrm{Fe}^{3+}, \mathrm{Zn}^{2+}, \mathrm{Mn}^{2+}, \mathrm{Cu}^{2+}$ ), in the 0-5 $\mathrm{cm}$ depth, as a function of the cover crops (plot) and year (subplot), Santo Antônio de Goiás, 2008/2009 and 2009/2010

\begin{tabular}{|c|c|c|c|c|c|c|}
\hline \multirow[t]{2}{*}{ Cover crop } & 2008 & 2009 & Average & 2008 & 2009 & Average \\
\hline & \multicolumn{3}{|c|}{$\operatorname{CEC~}\left(\mathrm{cmol}_{\mathrm{c}} \mathrm{dm}^{-3}\right)$} & \multicolumn{3}{|c|}{ BS (\%) } \\
\hline Fallow & $7.75 \mathrm{abA}$ & $8.82 \mathrm{cA}$ & 8.29 & $48.4 \mathrm{bB}$ & $51.1 \mathrm{abA}$ & 49.76 \\
\hline P. maximum & $7.33 \mathrm{cB}$ & $8.98 \mathrm{abA}$ & 8.16 & $55.2 \mathrm{aA}$ & $50.0 \mathrm{bA}$ & 52.34 \\
\hline B. ruziziensis & $7.31 \mathrm{cB}$ & $8.91 \mathrm{abA}$ & 8.11 & $55.7 \mathrm{aA}$ & $54.7 \mathrm{abA}$ & 55.13 \\
\hline B. brizantha & $8.00 \mathrm{aA}$ & $9.17 \mathrm{aA}$ & 8.48 & $48.6 \mathrm{bA}$ & $56.3 \mathrm{aA}$ & 50.73 \\
\hline P. glaucum & $7.55 \mathrm{bcB}$ & $8.51 \mathrm{bcA}$ & 8.03 & $57.0 \mathrm{aA}$ & $53.6 \mathrm{abA}$ & 55.18 \\
\hline \multirow[t]{2}{*}{ Average } & 7.59 & 8,88 & - & 52.99 & 52.52 & - \\
\hline & \multicolumn{3}{|c|}{$\mathrm{Fe}^{3+}\left(\mathrm{mg} \mathrm{dm}^{-3}\right)$} & \multicolumn{3}{|c|}{$\mathbf{Z n}^{2+}\left(\mathbf{m g ~ d m}^{-3}\right)$} \\
\hline Fallow & 28.5 & 26.0 & $27.25 \mathrm{c}$ & $3.53 \mathrm{cdB}$ & $4.80 \mathrm{bA}$ & 4.17 \\
\hline P. maximum & 27.7 & 29.8 & $28.71 \mathrm{bc}$ & $3.43 \mathrm{dA}$ & $4.27 \mathrm{cA}$ & 3.83 \\
\hline B. ruziziensis & 25.6 & 31.8 & $28.67 \mathrm{bc}$ & $4.43 \mathrm{aA}$ & $4.73 \mathrm{cA}$ & 4.59 \\
\hline B. brizantha & 32.2 & 35.2 & $33.69 \mathrm{a}$ & $4.17 \mathrm{abA}$ & $5.37 \mathrm{aA}$ & 4.78 \\
\hline P. glaucum & 33.2 & 30.1 & $31.67 \mathrm{ab}$ & $3.87 \mathrm{bcB}$ & $5.10 \mathrm{abA}$ & 4.48 \\
\hline \multirow[t]{2}{*}{ Average } & 29.43 & 30.58 & - & $3.89 \mathrm{~B}$ & $4.85 \mathrm{~A}$ & - \\
\hline & \multicolumn{3}{|c|}{$\mathrm{Mn}^{2+}\left(\mathrm{mg} \mathrm{dm}^{-3}\right)$} & \multicolumn{3}{|c|}{$\mathrm{Cu}^{2+}\left(\mathrm{mg} \mathrm{dm}^{-3}\right)$} \\
\hline Fallow & $21.6 \mathrm{aA}$ & $21.0 \mathrm{cA}$ & 21.25 & 2.0 & 1.4 & 1.70 \\
\hline P. maximum & $20.5 \mathrm{bA}$ & $21.7 \mathrm{cA}$ & 21.20 & 1.5 & 1.6 & 1.51 \\
\hline B. ruziziensis & $20.6 \mathrm{bA}$ & $25.7 \mathrm{bA}$ & 23.15 & 1.2 & 1.5 & 1.32 \\
\hline B. brizantha & $19.2 \mathrm{cB}$ & $31.0 \mathrm{aA}$ & 25.05 & 1.7 & 1.5 & 1.62 \\
\hline P. glaucum & $22.4 \mathrm{aB}$ & $26.6 \mathrm{bA}$ & 24.45 & 1.8 & 1.7 & 1.72 \\
\hline Average & 20.85 & 25.19 & - & 1,62 & 1.54 & - \\
\hline \multirow{2}{*}{ Factor } & \multicolumn{6}{|c|}{ ANOVA (Mean Square) } \\
\hline & CEC & BS & $\mathrm{Fe}^{3+}$ & $\mathbf{Z n}^{2+}$ & $\mathrm{Mn}^{2+}$ & $\mathrm{Cu}^{2+}$ \\
\hline Block & 0.265 & 21.218 & 0.722 & 0.013 & 0.032 & 0.128 \\
\hline Cover crop (CC) & $0.291^{* *}$ & 37.082 & $41.116^{*}$ & $0.791^{* *}$ & $19.573^{* *}$ & 0.151 \\
\hline Error (a) & 0.161 & 3.214 & 0.253 & 0.044 & 0.421 & 0.084 \\
\hline Year & $8.965^{* *}$ & 17.941 & 9.976 & $7.008^{* *}$ & $140.833^{* *}$ & 0.048 \\
\hline CC * Year & $0.611^{* *}$ & $70.300^{* * *}$ & 23.253 & $0.254^{* *}$ & $33.849^{* *}$ & 0.159 \\
\hline Error (b) & 0.084 & 6.617 & 0.651 & 0.042 & 1.193 & 0.067 \\
\hline CV Plot (\%) & 4.87 & 3.39 & 1.68 & 4.78 & 2.82 & 18.37 \\
\hline CV Subplot (\%) & 3.51 & 4.88 & 2.69 & 4.66 & 4.75 & 16.38 \\
\hline
\end{tabular}

$\S$ Means followed by the same letter, lowercase vertically or upper cases horizontally, do not differ by the LSD at $\mathrm{p} \leq 0.05$. CEC: cation exchange capacity, $\mathrm{BS}$ : base saturation, $\mathrm{Fe}^{3+}$ : iron, $\mathrm{Zn}^{2+}$ : zinc, $\mathrm{Mn}^{2+}$ : manganese, $\mathrm{Cu}^{2+}$ : copper. ${ }^{* *},{ }^{*}$ Significant at $\mathrm{p}<0.05$ and 0.01 , respectively. 
It could be observed that cation exchange capacity (CEC) of the soil under B. brizantha showed the highest values in the two years, although it did not differ significantly from some other cover crops
(Table 2), besides, the CEC was higher in the soil from 2008 to 2009 for the soil under $P$. maximum, $B$. ruziziensis and millet. In the year 2009, the CEC of the soil under all cover crops did not differ from the

Table 3: Comparison of the soil's chemical attributes ( $\mathrm{pH}, \mathrm{P}, \mathrm{Ca}^{2+}, \mathrm{Mg}^{2+}, \mathrm{K}^{+}, \mathrm{SOM}, \mathrm{CEC}, \mathrm{V}, \mathrm{Fe}^{3+}, \mathrm{Zn}^{2+}, \mathrm{Mn}^{2+}, \mathrm{Cu}^{2+}$ ), in the 0-5 cm depth, as a function of the cover crops with the initial fertility, Santo Antônio de Goiás, 2007/2008 (initial fertility), 2008/2009 and 2009/2010

\begin{tabular}{|c|c|c|c|c|c|c|}
\hline \multirow{2}{*}{ Cover crop } & 2008 & 2009 & 2008 & 2009 & 2008 & 2009 \\
\hline & \multicolumn{2}{|c|}{ pH (water) } & \multicolumn{2}{|c|}{$\mathbf{P}\left(\mathbf{m g ~ d m}{ }^{-3}\right)$} & \multicolumn{2}{|c|}{$\mathrm{Ca}^{2+}\left(\mathrm{cmol}_{\mathrm{c}} \mathrm{dm}^{-3}\right)$} \\
\hline Fallow & $6.3 \S$ & $5.8 *$ & $10.8 *$ & 13.3 & 2.57 & 2.83 \\
\hline P. maximum & $6.8 *$ & $5.6 *$ & 11.8 & 12.8 & 2.33 & 2.57 \\
\hline B. ruziziensis & $6.8 *$ & $5.8 *$ & 13.8 & 15.6 & 2.57 & $2.90 *$ \\
\hline B. brizantha & 6.4 & $5.7 *$ & 11.8 & 15.9 & 2.17 & $3.00 *$ \\
\hline P. glaucum & 6.7 & $5.9 *$ & $11.2 *$ & 16.7 & 2.70 & 2.90 \\
\hline Initial Fertility & 6.4 & 6.4 & 13.8 & 13.8 & 2.5 & 2.5 \\
\hline Factors & \multicolumn{6}{|c|}{ ANOVA (Mean Square) } \\
\hline Error & 0.0249 & 0.01377 & 0.6859 & 5.99566 & 0.0406 & 0.0332 \\
\hline LSD & 0.3852 & 0.2854 & 2.0221 & 5.9784 & 0.4917 & 0.4450 \\
\hline \multirow[t]{2}{*}{$\mathrm{CV}(\%)$} & 2.17 & 1.99 & 15.79 & 16.87 & 7.20 & 6.65 \\
\hline & \multicolumn{2}{|c|}{$\mathrm{Mg}^{2+}\left(\mathrm{cmol}_{\mathrm{c}} \mathrm{dm}^{-3}\right)$} & \multicolumn{2}{|c|}{$\mathrm{K}^{+}\left(\mathrm{cmol}_{\mathrm{c}} \mathbf{d m}^{-3}\right)$} & \multicolumn{2}{|c|}{$\operatorname{SOM}\left(\mathrm{g} \mathrm{dm}^{-3}\right)$} \\
\hline Fallow & 0.87 & $1.27 *$ & 0.38 & 0.34 & $18.4^{*}$ & $22.9^{*}$ \\
\hline P. maximum & 0.97 & $1.40^{*}$ & $0.61 *$ & $0.64^{*}$ & 20.6 & $23.0^{*}$ \\
\hline B. ruziziensis & 0.93 & $1.40^{*}$ & 0.51 & $0.54 *$ & 21.4 & $22.9^{*}$ \\
\hline B. brizantha & 0.90 & $1.57 *$ & $0.60 *$ & $0.62 *$ & $21.8 *$ & $23.9^{*}$ \\
\hline P. glaucum & $1.13^{*}$ & $1.27 *$ & 0.43 & $0.49^{*}$ & $21.6^{*}$ & $24.2^{*}$ \\
\hline Initial Fertility & 0.8 & 0.8 & 0.25 & 0.25 & 20.4 & 20.4 \\
\hline Factors & \multicolumn{6}{|c|}{ ANOVA (Mean Square) } \\
\hline Error & 0.0092 & 0.0286 & 0.0142 & 0.0049 & 0.2082 & 0.0130 \\
\hline LSD & 0.2345 & 0.4126 & 0.2912 & 0.1707 & 1.1141 & 0.2784 \\
\hline \multirow[t]{2}{*}{$\mathrm{CV}(\%)$} & 9.82 & 13.11 & 26.28 & 14.63 & 2.25 & 0.50 \\
\hline & \multicolumn{2}{|c|}{$\operatorname{CEC}\left(\mathrm{cmol}_{\mathrm{c}} \mathbf{d m}^{-3}\right)$} & \multicolumn{2}{|c|}{ BS (\%) } & \multicolumn{2}{|c|}{$\mathrm{Fe}^{3+}\left(\mathrm{mg} \mathrm{dm}^{-3}\right)$} \\
\hline Fallow & $7.75 *$ & 8.82 & 48.4 & 51.1 & 28.5 & 26.0 \\
\hline P. maximum & 7.33 & 8.98 & 55.2 & 50.0 & 27.7 & 29.8 \\
\hline B. ruziziensis & 7.31 & 8.91 & 55.7 & 54.7 & 25.6 & $31.8^{*}$ \\
\hline B. brizantha & $8.00 *$ & 9.17 & 48.6 & 53.3 & 32.2 & $35.2 *$ \\
\hline P. glaucum & 7.55 & 8.51 & $57.0^{*}$ & 56.3 & 33.2 & 30.1 \\
\hline Initial Fertility & 7.05 & 7.05 & 50.32 & 50.32 & 27.60 & 27.60 \\
\hline Factors & \multicolumn{6}{|c|}{ ANOVA (Mean Square) } \\
\hline Error & 0.1166 & 8.8726 & 8.2306 & 8.8726 & 7.5699 & 2.5463 \\
\hline LSD & 0.8336 & 0.6843 & 7.0046 & 7.2726 & 6.7176 & 3.8961 \\
\hline \multirow[t]{2}{*}{$\mathrm{CV}(\%)$} & 4.36 & 5.62 & 5.28 & 3.30 & 9.63 & 5.30 \\
\hline & \multicolumn{2}{|c|}{$\mathrm{Zn}^{2+}\left(\mathrm{mg} \mathrm{dm}^{-3}\right)$} & \multicolumn{2}{|c|}{$\mathrm{Mn}^{2+}\left(\mathrm{mg} \mathrm{dm}^{-3}\right)$} & \multicolumn{2}{|c|}{$\mathrm{Cu}^{2+}\left(\mathrm{mg} \mathrm{dm}^{-3}\right)$} \\
\hline Fallow & $3.53 *$ & 4.80 & $21.6^{*}$ & 21.0 & 2.0 & $1.4^{*}$ \\
\hline P. maximum & $3.43 *$ & $4.27 *$ & $20.5^{*}$ & $21.7^{*}$ & 1.5 & $1.6^{*}$ \\
\hline B. ruziziensis & 4.43 & 4.73 & $20.6^{*}$ & $25.7 *$ & 1.2 & $1.5^{*}$ \\
\hline B. brizantha & $4.17 *$ & 5.37 & 19.2 & $31.0^{*}$ & 1.7 & $1.5^{*}$ \\
\hline P. glaucum & $3.87 *$ & 5.10 & $22.4 *$ & $26.6^{*}$ & 1.8 & 1.7 \\
\hline Initial Fertility & 5.1 & 5.1 & 18.1 & 18.1 & 1.9 & 1.9 \\
\hline Factors & \multicolumn{6}{|c|}{ ANOVA (Mean Square) } \\
\hline Error & 0.07956 & 0.1072 & 0.5306 & 1.6150 & 0.0950 & 0.0123 \\
\hline LSD & 0.6887 & 0.7995 & 1.7784 & 3.1028 & 0.7525 & 0.2711 \\
\hline $\mathrm{CV}(\%)$ & 7.79 & 6.69 & 1.78 & 5.29 & 19.05 & 6.94 \\
\hline
\end{tabular}

$\S$ Means followed by * differed from control treatment (initial fertility) by Dunnet's test for $p \leq 0.05$. LSD: least significant difference.

Rev. Ceres, Viçosa, v. 62, n.4, p. 401-409, jul-ago, 2015 
initial fertility at 2007 (Table 3). Moreti et al. (2007), Garcia \& Rosolem (2010), and Cunha et al. (2011) reported that the use of cover crops with a constant input of biomass on the soil surface can alter the contents of soil nutrients in a relatively short time. Crusciol et al. (2010), in only one harvest also observed a significant increase in soil CEC due to $B$. brizantha cultivation.

The base saturation (BS) of the soil under $P$. maximum, B. ruziziensis and millet showed the highest values in 2008, however soil BS under P. maximum was lower than under B. brizantha, in 2009 (Table 2). In addition, soil BS was higher from 2008 to 2009 only for the soil under fallow. In the year 2009, the soil BS under all cover crops did not differ from the initial fertility found in 2007 (Table 3).

Fabian (2009), working with Brachiaria brizantha and Crotalaria juncea, found that these cover crops provided for an increase in the contents of SOM, and reported that this feature can have positive effects on soil CEC and BS. According to Crusciol et al. (2010), CEC and BS are reflections of the organic matter content and soil nutrients. Additionally, they reported that due to crop residue on the soil surface, there is a greater amount of organic matter in the soil surface, especially in the 0-5 cm layer. Therefore, in our trial, observing the soil chemical changes under the majority of the cover crops used, it seems clear that the decomposition of the residues provided an extra amount of nutrients to the soil surface, as well as significant increases in the content of soil organic matter (Table 1) and soil CEC (Table 2). In this sense, it was observed that almost all the contents of nutrients showed increases from one year to the next (Table 1 and 2); it may be due the annual input of biomass in the system that contributes significantly to add nutrients to the soil. In other words, the longer the no-tillage system is used, the longer the benefits to the agricultural systems, mainly in terms of soil fertility (Bernardi et al., 2003). Grasses like P. maximum, B. ruziziensis, and $B$. brizantha are normally related to produce high amounts of biomass (Kluthcouski et al., 2000; Moreti et al., 2007; Crusciol et al., 2008; Rosolem et al., 2010; Pacheco et al., 2011; Nascente \& Crusciol, 2012) and therefore, will probably contribute significantly to increased soil fertility as was observed in our trial.

Regarding micronutrients, soil under B. brizantha, on average, allowed the highest value of iron and differed from other cover crops, however it was similar to the soil under millet (Table 2). In relation to zinc, soil with B. ruziziensis, B. brizantha in the year 2008 and under B. brizantha and millet in the year 2009 provided the highest values. In soil under fallow and millet in 2008 and under B. brizantha in 2009 we observed the highest values of manganese. Regarding copper, there was no effect of cover crops or years. It is important to note that there was no fertilization with micronutrients in the area, and there were observed increases in the level of micronutrients in comparison to the initial fertility in 2007 (Table 3). Thus, there is an outstanding advantage of using cover crops in order to increase the contents of soil nutrients, especially for soils of the Cerrado, characterized as being nutritionally poor (Bernardi et al., 2003). According to these authors, there has been an increase in micronutrient deficiencies in the Cerrado, mainly due to the low natural fertility of these soils. Therefore, the introduction of cover crops can increase the contents of these nutrients in the soil and reduce the application of fertilizers, leading to lower costs of production and contributing to the sustainability of the system. Cunha et al. (2011), worked with cover crops and reported that they were not able to maintain the same soil contents of $\mathrm{Fe}^{2+}$ and $\mathrm{Mn}^{2+}$. In spite of that, in our trial, millet, B. ruziziensis, and P. maximum stood out for the increase in the soil content of $\mathrm{Mn}^{2+}$ in both years. B. ruziziensis also contributes to increase the soil content of $\mathrm{Fe}^{3+}$ (2009); B. brizantha provided for an increase in the soil contents of $\mathrm{Fe}^{3+}$ and $\mathrm{Mn}^{2+}$ (2009); and fallow provided for an increase in the $\mathrm{Mn}^{2+}$ (2008). In this sense, Franzluebbers \& Hons (1996) also found increases in $\mathrm{Zn}^{2+}, \mathrm{Mn}^{2+}, \mathrm{Fe}^{3+}$, and $\mathrm{Cu}^{2+}$ in soil under cover crops. Fallow did not show that it could maintain soil micronutrient contents in both years.

It is important to notice that although we had differences among some soil attributes, these differences, in the majority of attributes, were low because it was only two years of evaluation. The only exception was potassium, which is expected since this nutrient is very mobile in the soil (Malavolta, 1980). It is likely that if we had more years of evaluations the differences among the average of soil attributes would increase.

\section{CONCLUSIONS}

The use of cover crops provided significant increases in the contents of the soil nutrients, soil organic matter, soil cation exchange capacity and soil base saturation. Soil fertility had improved from the first to the second year with growing cover crops;

The cover crops Pennisetum glaucum, Brachiaria ruziziensis and $B$. brizantha contributed more to increase soil fertility than fallow plots. 


\section{ACKNOWLEDGMENTS}

We would like to thank Embrapa (Brazilian Agricultural Research Corporation), for supporting this research and for providing a scholarship to the second an third author, and to CNPq (National Council of Scientific and Technological Development), for providing a scholarship to the second author.

\section{REFERENCES}

Bernardi ACC, Verruma-Bernardi MR, Werneck CG, Haim PG \& Monte MBM (2005) Yield, appearance and content of nitrogen, phosphorus and potassium in lettuce grown in substrate with zeolite. Horticultura Brasileira, 23:920-924.

Bernardi ACC, Machado PLOA, Freitas PL, Coelho MR, Leandro WM, Oliveira Júnior JP, Oliveira RP, Santos HG, Madari BE \& Carvalho MCS (2003) Soil liming and fertilization in the no tillage system at Cerrado. Rio de Janeiro, Embrapa Solos. 22p.

Boer CA, Assis RL, Silva GP, Braz AJBP, Barros ALL, Cargnelutti Filho A \& Pires FR (2007) Nutrient cycling in off-season cover crops on a Brazilian savanna soil. Pesquisa Agropecuária Brasileira, 42:12691276.

Caires EF, Corrêa JCL, Churka S, Barth G \& Garbuio FJ (2006) Surface application of lime ameliorates subsoil acidity and improves root growth and yield of wheat in an acid soil under no-till system. Scientia Agricola, 63:502-509.

Carneiro MAC, Souza ED, Reis EF, Pereira HS \& Azevedo WR (2009) Physical, chemical and biological properties of cerrado soil under different land use and tillage systems. Revista Brasileira de Ciência do Solo, 33:147-157.

Carpim LK, Assis RL, Braz AJBP, Silva GP, Pires FR, Pereira VC, Gomes GV \& Silva AG (2008) Nutrient release from pearl millet in different phenological stages. Revista Brasileira de Ciência do Solo, 32:28132819.

Claessen MEC (1997) Manual for Methods of Soil Analysis, $2^{\text {nd }}$ ed. Rio de Janeiro, Embrapa Solos. 212p.

Crusciol CAC, Moro E, Lima EV \& Andreotti M (2008) Decomposition rate and nutrient release of oat straw used as mulching in no-till system. Bragantia, 67:481-489.

Crusciol CAC, Cottica RL, Lima EV, Andreotti M, Moro E \& Marcom E (2005) Persistence and nutrients release of forage turnip straw utilized as mulching in no-tillage crop system. Pesquisa Agropecuária Brasileira, 40:161-168.

Crusciol CAC, Soratto RP, Borghi E \& Matheus GP (2010) Benefits of Integrating Crops and Tropical Pastures as Systems of Production. Better Crops, 94:14-16.

Cunha EQ, Stone LF, Didonet AD, Ferreira EPB, Moreira JAA \& Leandro WM (2011) Chemical attributes of soil under organic production as affected by cover crops and soil tillage. Revista Brasileira de Engenharia Agrícola e Ambiental, 15:1021-1029.

Duda GP, Guerra JGM, Monteiro MT, De-Polli H \& Teixeira MG (2003) Perennial herbaceous legumes as live soil mulches and their effects on C, N and P of the microbial biomass. Scientia Agricola, 60:139-147.

Embrapa Arroz e Feijão (2003) Upland rice cultivation. Available at: <http://sistemasdeproducao.cnptia.embrapa.br/FontesHTML/Arroz/ ArrozTerrasAltas/expediente.htm>. Accessed on: September $29^{\text {th }}$, 2012

Embrapa (1999) National system of soil classification. Rio de Janeiro, Embrapa Solos. 306p.
Fabian A (2009) Cover crops: effects in the soil attributes and in the productivity of corn and soybean in rotation schemes. Doctoral thesis. Universidade estadual Paulista, Jaboticabal. 99p.

Falleiro RM, Souza CM, Silva CSW, Sediyama CS, Silva AA \& Fagundes JL (2003) Influence of tillage systems on the chemical and physical attributes of a soil. Revista Brasileira de Ciência do Solo, 27:10971104.

Franchini JC, Borkert CM, Ferreira MM \& Gaudêncio CA (2000) Soil fertility changes on no-tillage crop rotation systems. Revista Brasileira de Ciência do Solo, 24:459-467.

Franzluebbers AJ \& Hons FM (1996) Soil-profile distribution of primary and secondary plant-avaliable nutrients under conventional and no tillage. Soil \& Tillage Research, 39:229-239.

Garcia RA, Crusciol CAC, Calonego JC \& Rosolem CA (2008) Potassium cycling in a corn-brachiaria cropping system. European Journal of Agronomy, 28:579-585.

Garcia RA \& Rosolem CA (2010) Aggregates in a Rhodic Ferralsol under no-tillage and crop rotation. Pesquisa Agropecuária Brasileira, 45:1489-1498.

Guimarães GL (2000) Effect of winter crops and fallow in the crop rotation of soybeans and corn in no-tillage system. Master dissertation. Universidade Estadual Paulista, Ilha Solteira. 104p.

Kluthcouski J, Cobucci T, Aidar H, Yokoyama LP, Oliveira IP, Costa JLS, Silva JG, Vilela L, Barcellos AO \& Magnabosco CU (2000) Sistema Santa Fé - Tecnologia Embrapa: integração lavoura-pecuária pelo consórcio de culturas anuais com forrageiras, em áreas de lavoura, nos sistemas direto e convencional. Santo Antônio de Goiás, Embrapa Arroz e Feijão. 28p.

Malavolta E (1980) Element of mineral plant nutrition. São Paulo, Agronômica Ceres. 251p.

Mello JCA, Villas-Boas RL, Lima EV, Crusciol CAC \& Büll LT (2003) Changes of chemical soil characteristics due to doses and particle sizes of limestone in no-tillage and conventional systems. Revista Brasileira de Ciência do Solo, 27:553-561.

Moreti D, Alves MC, Valerio Filho WV \& Carvalho MP (2007) Soil chemical attributes of a red latosol under different systems of preparation, management, and covering plants. Revista Brasileira de Ciência do Solo, 31:167-175.

Nascente AS \& Crusciol CAC (2012) Cover crops and herbicide timing management on soybean yield under no-tillage system. Pesquisa Agropecuária Brasileira, 47:187-192.

Nascente AS, Crusciol CAC \& Cobucci T (2013) The no-tillage system and cover crops - Alternatives to increase upland rice yield. European Journal of Agronomy, 45:124-131.

Oliveira EL \& Pavan MA (1996) Control of soil acidity in no-tillage system for soybean production. Soil \& Tillage Research, 38:47-57.

Pacheco LP, Leandro WM, Machado PLOA, Assis RL, Cobucci T, Madari BE \& Petter FA (2011) Biomass production and nutrient accumulation and release by cover crops in the off-season. Pesquisa Agropecuária Brasileira, 46:17-25.

Reddy SS, Nyakatawa EZ, Reddy KC, Raper RL, Reeves DW \& Lemunyon JL (2009) Long-term effects of poultry litter and conservation tillage on crop yields and soil phosphorus in cottoncotton-corn rotation. Field Crops Research, 114:311-319.

Rosolem CA, Santos FP, Foloni JSS \& Calonego JC (2006) Soil potassium as affected by fertilization over the millet straw and simulated rain. Pesquisa Agropecuária Brasileira, 41:1033-1040.

Rosolem CA, Werle R \& Garcia RA (2010) Nitrogen washing from C3 and $\mathrm{C} 4$ cover grasses residues by rain. Revista Brasileira de Ciência do Solo, 34:1899-1905.

Rev. Ceres, Viçosa, v. 62, n.4, p. 401-409, jul-ago, 2015 
Sá JCM (1993) Soil fertility management in no-tillage system. Castro, Fundação ABC. 96p.

Santi A, Amado TJC \& Acosta JAA (2003) Black oat biomass and nutrient cycling as affected by nitrogen fertilization in soil under no-tillage. Revista Brasileira de Ciência do Solo, 27:1075-1083.

Santos HP \& Tomm GO (2003) Nutrient availability and organic matter content as affected by croppings systems and soil management. Ciência Rural, 33:477-486.

SAS - Statistics Analyses Systems (1999) Procedure guide for personal computers: Version 5. Cary, Statistics Analyses Systems Institute. CD-ROM.
Soratto RP \& Crusciol CAC (2007) Water-soluble cations in shoots of annual crops as affected by lime and phosphogypsum surface application. Revista Brasileira de Ciência do Solo, 31:81-90.

Torres JLR \& Pereira MG (2008) Potassium dynamics in crop residues of cover plants in Cerrado. Revista Brasileira de Ciência do Solo, 32:1609-1618.

Torres JLR, Pereira MG, Andrioli I, Polidoro JC \& Fabian AJ (2005) Cover crops residue decomposition and nitrogen release in a cerrado soil. Revista Brasileira de Ciência do Solo, 29:609-618. 